\title{
ECONOMIC ANALYSIS OF NUCLEAR REACTORS
}

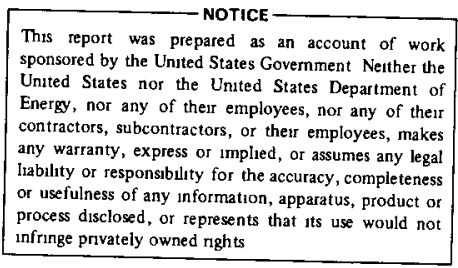

\section{Hanford Engineering Development Laboratory \\ P. S. Owen, M. B. Parker, and R. P. Omberg}

May 1979

HANFORD ENGINEERING DEVELOPMENT LABORATORY

Operated by Westinghouse Hanford Company

P.0. Box 1970 Richland, WA 99352

A Subsidiary of Westinghouse Electric Corporation

Prepared for the U.S. Department of Energy under Contract No. EY-76-C-14-2170 


\section{DISCLAIMER}

This report was prepared as an account of work sponsored by an agency of the United States Government. Neither the United States Government nor any agency Thereof, nor any of their employees, makes any warranty, express or implied, or assumes any legal liability or responsibility for the accuracy, completeness, or usefulness of any information, apparatus, product, or process disclosed, or represents that its use would not infringe privately owned rights. Reference herein to any specific commercial product, process, or service by trade name, trademark, manufacturer, or otherwise does not necessarily constitute or imply its endorsement, recommendation, or favoring by the United States Government or any agency thereof. The views and opinions of authors expressed herein do not necessarily state or reflect those of the United States Government or any agency thereof. 


\section{DISCLAIMER}

Portions of this document may be illegible in electronic image products. Images are produced from the best available original document. 


\section{ECONOMIC ANALYSIS}

\section{Introduction}

Decisions concerning the development or deployment of nuclear reactor options may be based in part on economics. This report presents several methods for estimating the power costs of nuclear reactors. When based on a consistent set of economic assumptions, total power costs may be useful in comparing reactor alternatives.

The principal items contributing to the total power costs of a nuclear power plant are:

capita1 costs

fuel cycle costs

operation and maintenance costs

income taxes and fixed charges.

There is a large variation in capital costs and fuel expenses among different reactor types. For example, the standard once-through LWR has relatively low capital costs; however, the fuel costs may be very high if $\mathrm{U}_{3} \mathrm{O}_{8}$ is expensive. In contrast, the FBR has relatively high capital costs but low fuel expenses. Thus, the distribution of expenses varies significantly between these two reactors. In order to compare power costs, expenses and revenues associated with each reactor may be spread over the lifetime of the plant. A single annual cost, often called a "levelized" cost, may be obtained by the methods described in subsequent sections. Levelized power costs may then be used as a basis for economic comparisons.

This paper will first discuss each of the power cost components. An exact expression for total levelized power costs will then be derived. Finally, approximate techniques of estimating power costs will be presented. 
Basic Concept of the Time Variability of Money

Time-dependent value of money is an important concept in an economy study. The time value of money will first be developed in terms of interest paid on borrowed money. For example, consider an amount, C, that is borrowed for a year. At the end of the year, the same amount must be repaid and in addition, the interest on that amount must be paid out. If $i$ represents the interest rate, the amount that must be paid back at the end of the year is:

$$
\text { (payback) }=\mathrm{C}+\mathrm{iC}=\mathrm{C}(1+\mathrm{i})
$$

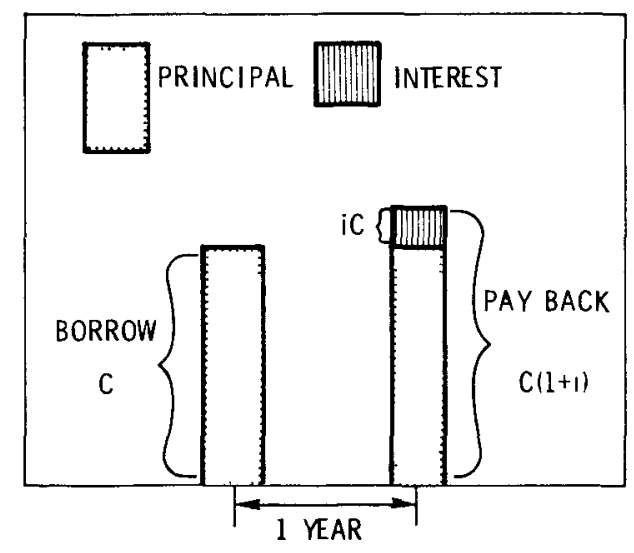

\section{BORROWING CAPITAL FOR ONE YEAR}

Alternatively, an interest rate can be used to describe the value today of an expense that is anticipated in the future. For example, consider an expense, $\mathrm{C}$, that must be paid at the end of a year. At the beginning of that year, an amount $C^{\prime}$ may be set aside (or invested) such that the future expense may be met. At the end of the year, the amount available for payout is:

$$
\text { (payout) }=C^{\prime}+i C^{\prime}=C^{\prime}(1+i)
$$

But this must be equal to $\mathrm{C}$, so: 


$$
C^{\prime}(1+i)=C
$$

and

$$
C^{\prime}=\frac{C}{1+i}
$$

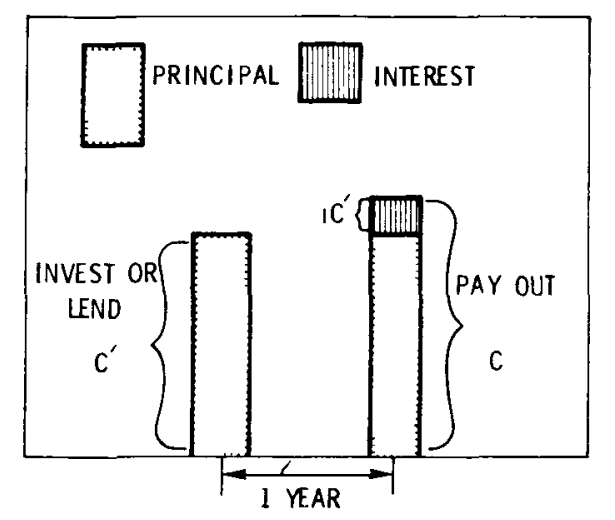

\section{INVESTING CAPITAL FOR ONE YEAR}

These two examples may now be extended to develop the concept of the presentworth of an expense or revenue occurring at any point in time. With the present-worth technique, one can find an amount of money in Year 0 that is equivalent to an expense or revenue in some other year. The present-worth concept will be used to handle costs that occur throughout the life of a nuclear plant in a systematic fashion.

The first case involves finding the present-value of a cost that occurs in the past. For example, assume the amount $C$ was paid out two years ago. This expense may equivalently be expressed as:

$$
\begin{array}{ll}
C & \text { in Year }-2 \\
C+i C=C(1+i) & \text { in Year }-1 \\
C(1+i)+i C(1+i)=C(1+i)^{2} & \text { in Year } 0
\end{array}
$$

and $C(1+i)^{2}$ is the present-worth of a cost $C$ that occurs in Year -2 . 


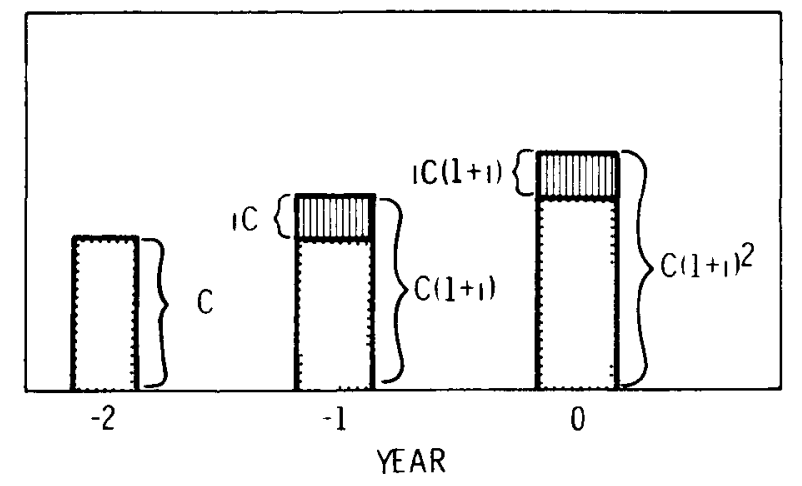

PRESENT-VALUE OF AN EXPENSE IN THE PAST

This may be extended to an expense $C$ which occurred $n$ years in the past. The present-value of such an expense is $C(1+i)^{n}$.

Conversely, an expense that is anticipated several years in the future may a1so be present-valued to Year 0. For example, let $C^{\prime}$ represent the present-worth of an expense $\mathrm{C}$ that occurs in Year 2. The following expenses are equivalent:

$$
\begin{aligned}
& C^{\prime} \text { in Year } 0 \\
& C^{\prime}+i C^{\prime}=C^{\prime}(1+i) \text { in Year } 1 \\
& C^{\prime}(1+i)+i C^{\prime}(1+i)=C^{\prime}(1+i)^{2} \text { in Year } 2
\end{aligned}
$$

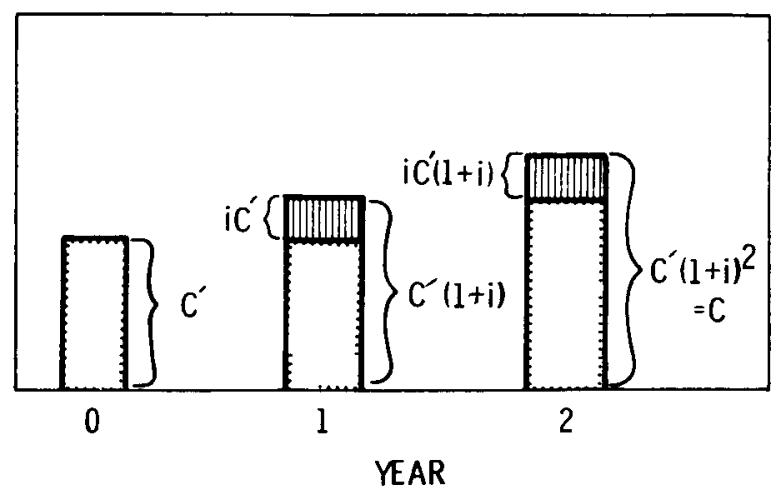


But $C^{\prime}(1+i)^{2}$ must equal $C$, the amount due in Year 2.

$$
\text { So } \begin{gathered}
C^{\prime}(1+i)^{2}=C, \\
C^{\prime}=\frac{C}{(1+i)^{2}}
\end{gathered}
$$

and this is the present-value of a cost $C$ that occurs in Year 2.

This may be extended to an expense $C$ which will occur $n$ years in the future. The present-worth of such a future expense is $\frac{C}{(1+i)^{n}}$.

The present-worth concept may be applied to all the fuel costs associated with one batch of nuclear fuel. An LWR on the once-through cycle is used in this example. Before the batch is loaded into the reactor, costs associated with $\mathrm{U}_{3} \mathrm{O}_{8}$ purchase, conversion and enrichment, and fabrication of fuel assemblies must be paid. After the fuel is discharged from the reactor, there are

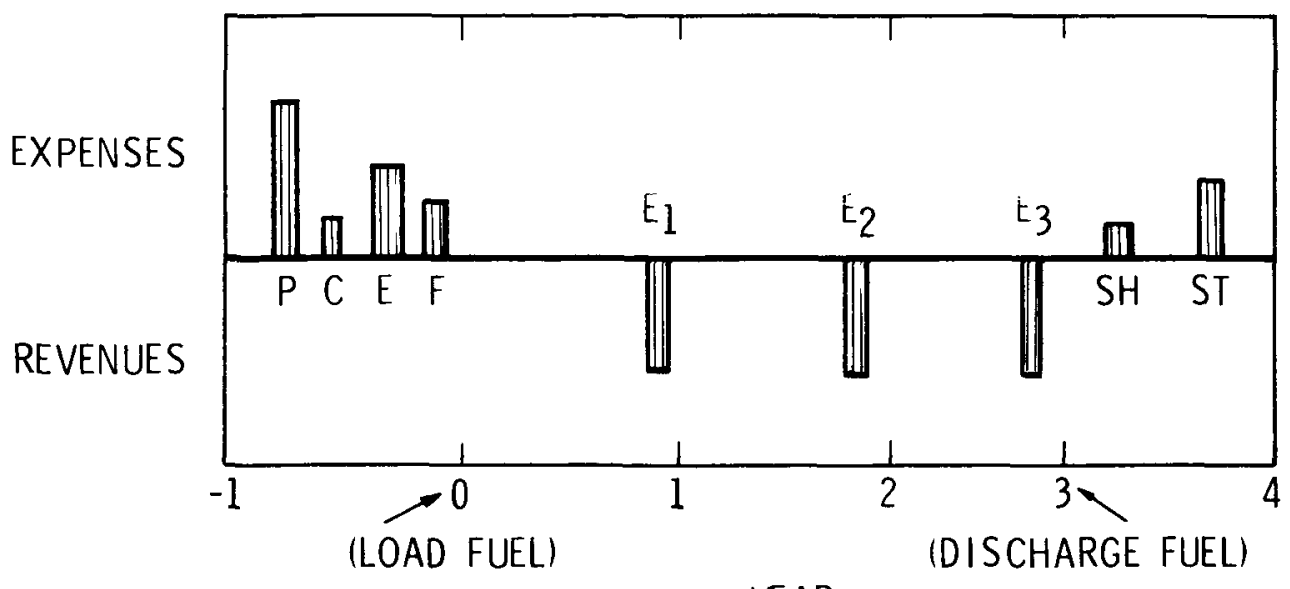

YEAR
P: PURCHASE $U_{30}$
C: CONVERSION
E: ENRICHMENT
F: FABRICATION 
expenses associated with spent fuel shipping and storage. Revenues from the sale of electricity produced by the batch occur throughout the years the batch is in the reactor. However, for simplification, it will be assumed that revenues occur at the end of each year of reactor operation.

Al1 the expenses and revenues may be present-valued to Year 0 , the year in which the fuel is loaded into the reactor. The present-valued expenses may be expressed as:

$$
P(1+i)+C(1+i)+E(1+i)+F(1+i)+\frac{S H}{(1+i)^{4}}+\frac{S T}{(1+i)^{4}}
$$

The sum of the present-valued revenues is:

$$
\frac{E_{1}}{1+i}+\frac{E_{2}}{(1+i)^{2}}+\frac{E_{3}}{(1+i)^{3}}
$$

Uniform Annual Costs

The costs associated with nuclear power plants occur in a nonumiform fashion. The capital expenses occur at the beginning of plant operation, while fuel cycle and operating costs occur throughout the plant lifetime. There are several techniques to reduce these nonuniform expenses to equivalent uniform costs. The uniform or "levelized" costs may be used to compare the economics of different reactor types.

As an example of levelizing expenses, consider an amount of money, C, that is borrowed in Year 0 . A constant annual cost, L, will be determined such that the debt and its accumulated interest are repaid by the end of the pay-off period. 


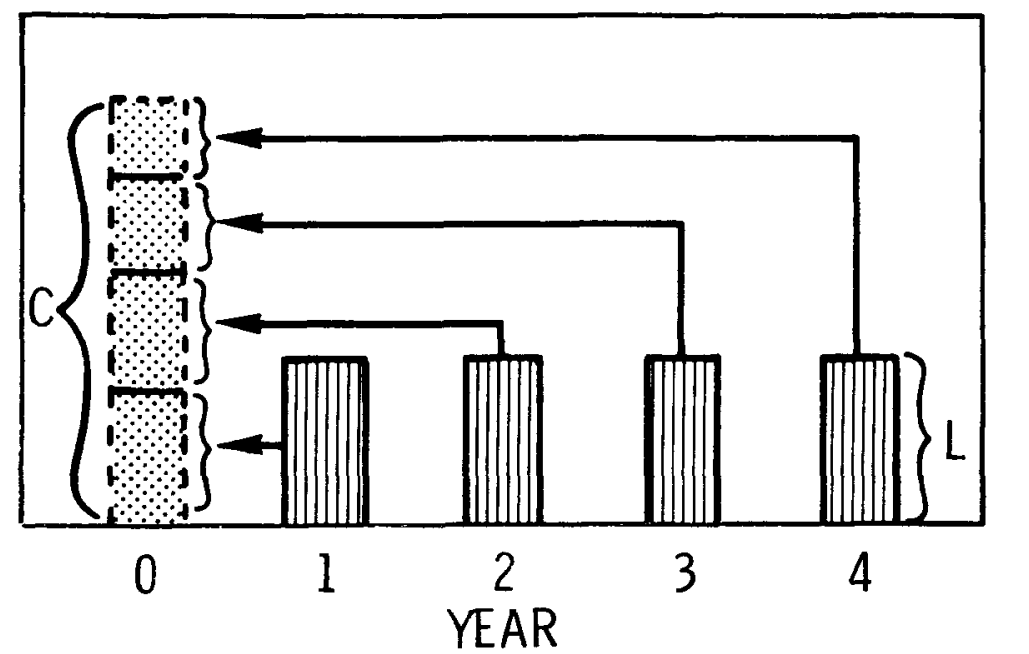

LEVELIZING A CAPITAL INVESTMENT

Although a constant amount, $\mathrm{L}$, is paid out each year, it is worth different amounts when present-valued to Year 0 . The present worth of the sum of the levelized expenses in the preceding example is:

$$
\frac{L}{(1+i)}+\frac{L}{(1+i)^{2}}+\frac{L}{(1+i)^{3}}+\frac{L}{(1+i)^{4}}
$$

This sum may be set equal to the initial investment, $C$, to obtain an expression for $L$ :

$$
\begin{aligned}
& C=L\left(\frac{1}{1+i}+\frac{1}{(1+i)^{2}}+\frac{1}{(1+i)^{3}}+\frac{1}{(1+i)^{4}}\right) \\
& L=\frac{C}{\sum_{k=1}^{4} \frac{1}{(1+i)^{k}}}
\end{aligned}
$$

This may be generalized for a pay-off time of any number of years, $\mathrm{K}$ :

$$
L=\frac{C}{\sum_{k=1}^{K} \frac{1}{(1+i)^{k}}}
$$


With some mathematical manipulation, it can be shown that this is equivalent to:

$$
L=C \times\left[\frac{i x(1+i)^{K}}{(1+i)^{K}-1}\right]
$$

This is referred to as an amortization formula.

This levelizing procedure may be applied to the initial capital investment of a nuclear power plant. The initial capital costs and interest during construction may be levelized over the full 30 years of plant operation.

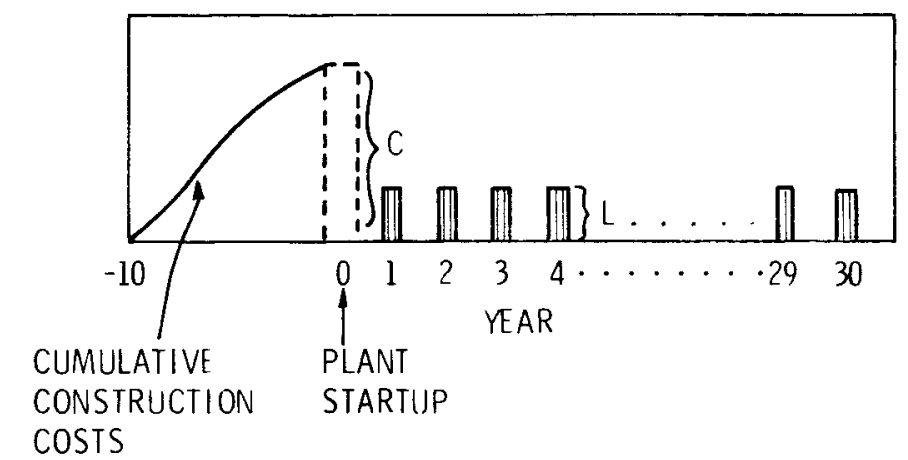

\section{LEVELIZING A CAPITAL INVESTMENT (INCLUDING INTEREST DURING CONSTRUCTION) OVER THE PLANT LIFETIME}

\section{Capital Payback Methods}

In the previous section, a technique for levelizing capital expenses and associated interest payments was discussed. This section will present several methods of distributing the levelized cost between principal and interest payments.

Capital investments for nuclear plants are usually financed by a mixture of both equity funds (stocks) and borrowed funds (bonds). A typical debt fraction is $55 \%$, with a $45 \%$ equity fraction. Typical uninflated interest rates for debt and equity are $2.5 \%$ and $7.0 \%$, respectively. 
There are several common ways to pay off a capital investment that is a mixture of both debt and equity. In the fixed payment method, it is assumed that the schedule of bond repayment is known in advance. The schedule may be in any of the following forms:

- uniform annual reduction of bond principal

- uniform annual payment, including both principal and interest

- any other specified schedule of principal reduction

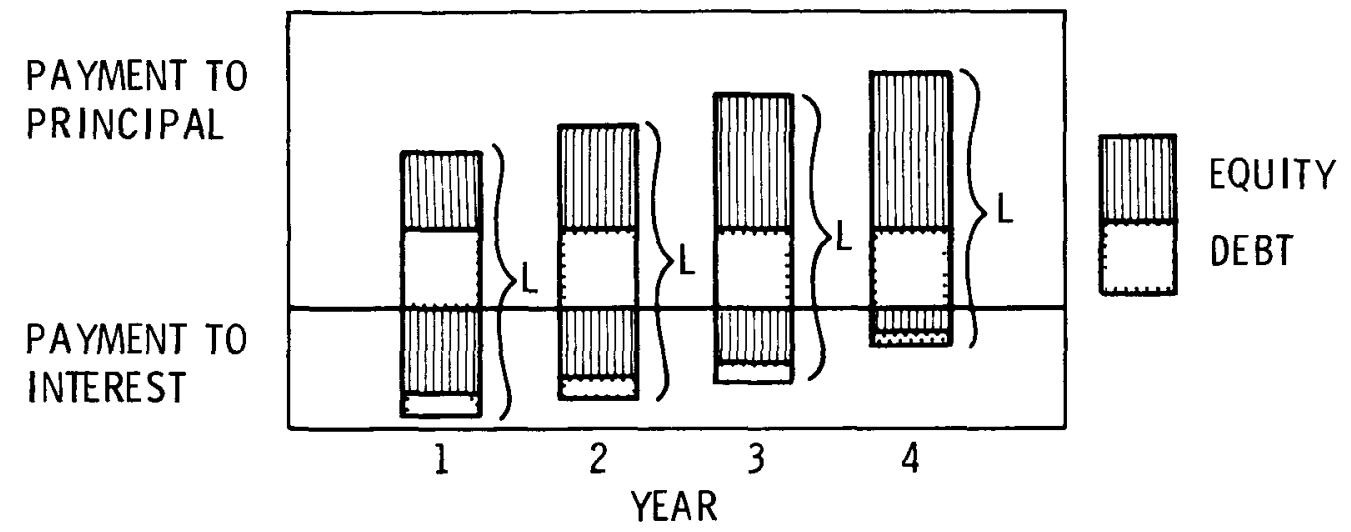

LEVELIZED CAPITAL PAYBACK - FIXED PAYMENT METHOD

Note that the payment to debt principal remains constant as a function of time while the payment to equity principal increases in this example.

A small utility with only a few large power plants may choose to follow a predetermined schedule for bond repayment. However, a large utility with a number of projects may elect to maintain a constant debt-to-equity ratio throughout the life of the plant. This is known as the proportional method of capital payback. 


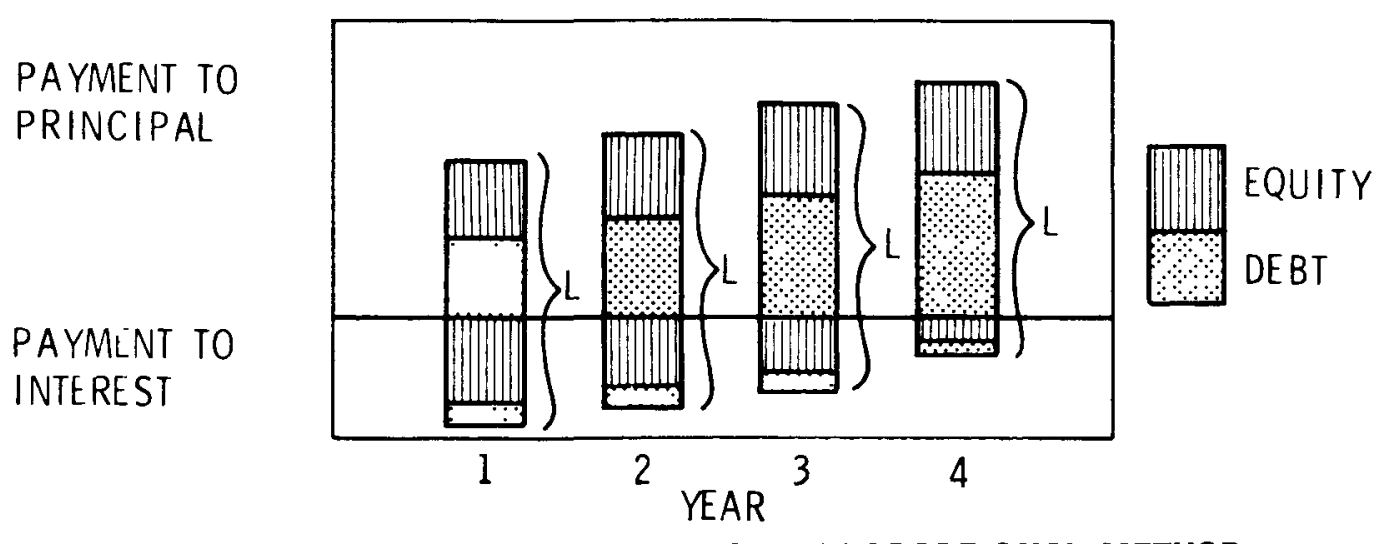

LEVELIZED CAPITAL PAYBACK - PROPORTIONAL METHOD

Note that the payments to both bond and equity principal increase.

When the ratio of the outstanding debt to outstanding equity is held constant, an effective rate of return of the combination of debt and equity may. be defined. For the typical values given earlier,

$$
\begin{aligned}
\left(\begin{array}{c}
\text { effective rate } \\
\text { of return }
\end{array}\right) & =(0.025 \times 0.55)+(0.07 \times 0.45) \\
& =0.045 \text { or } 4.5 \%
\end{aligned}
$$

This may also be referred to as a discount rate.

Income Taxes

Taxes on net income are an annual operating expense, similar to fuel costs and operating expenses. However, taxes are more complex than these other expenses due to tax deductions. The major tax deductions are:

- nonfue1 operating costs, such as 1abor, maintenance, state and local taxes, and insurance premiums

- interest paid on bonds

- depreciation a1lowance on both capita1 and fuel 
Income taxes may now be represented as:

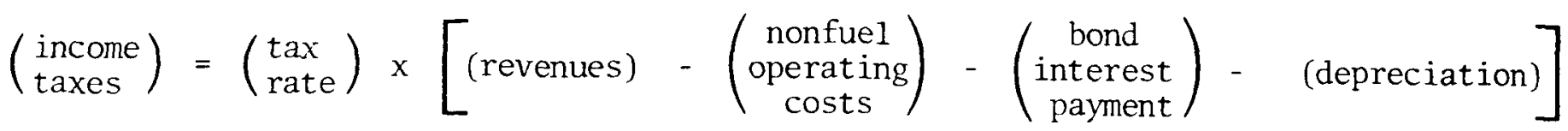

The depreciation allowance on capital may be calculated by several methods. The straight-line method assumes deductions due to depreciation are constant throughout the lifetime of the plant. Let $C$ represent the initial capital investment, $\mathrm{T}$ the project life, and $\mathrm{D}_{\mathrm{n}}$ the depreciation allowance in year $\mathrm{n}$. Then for straight-1ine depreciation:

$$
\mathrm{D}_{\mathrm{n}}=\frac{\mathrm{C}}{\mathrm{T}}
$$

An alternative is the sum-of-years digits method. With this method, the largest deductions are taken early in the plant life and the depreciation deduction decreases with time. This is represented by:

$$
D_{n}=\frac{C(T+1-n)}{\sum_{t=1}^{T} t}
$$

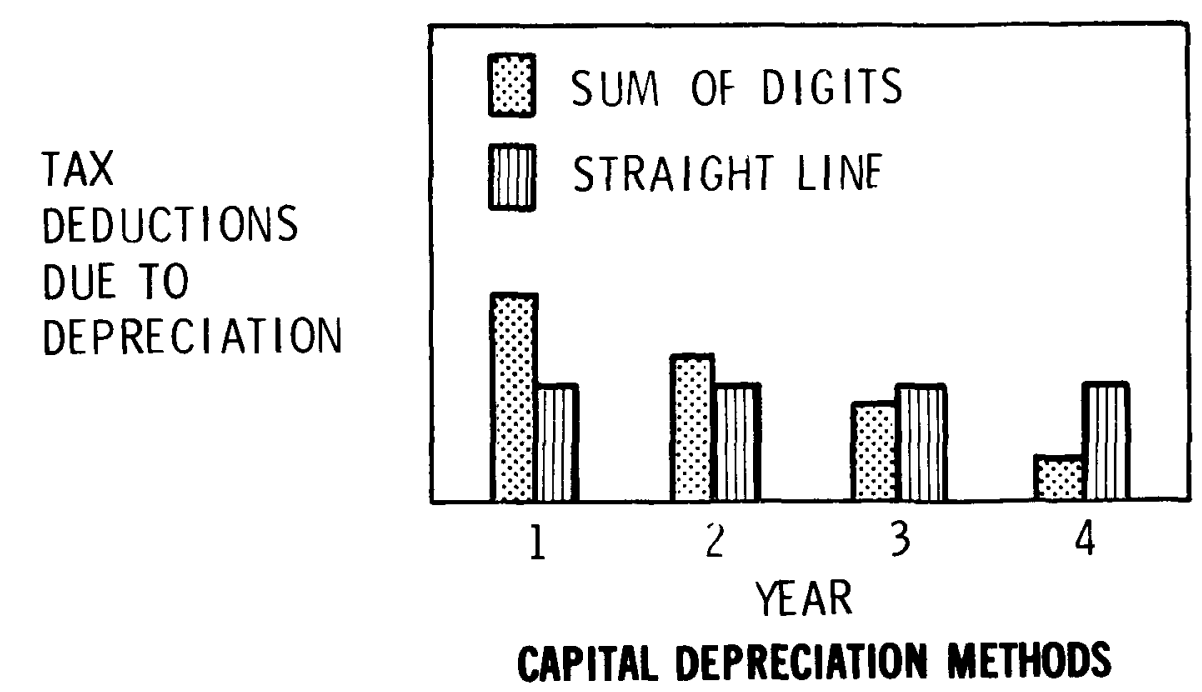


The sum-of-years digit method is usually preferred since it produces the lowest taxes in the early years of the project. Note that revenues and operating costs are relatively constant. The tax trends illustrated below include deductions due to bond interest and sum-of-years digits depreciation.

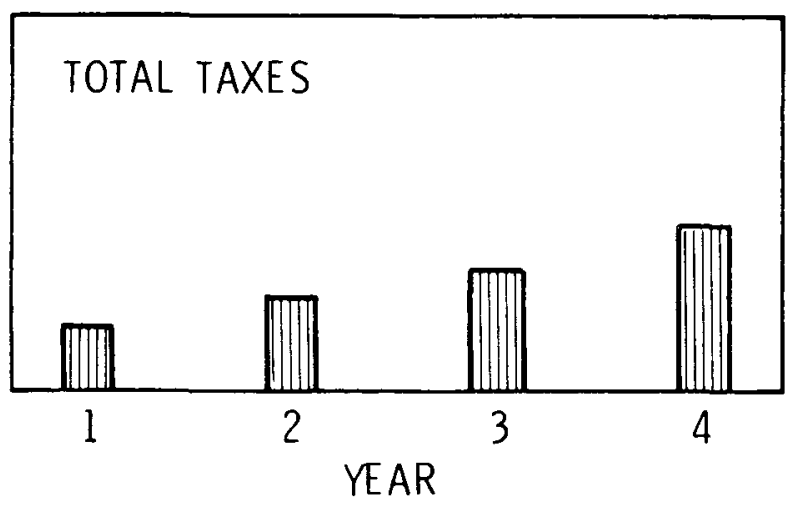

\section{GENERAL TAX TRENDS WITH SUM-OF-YEARS DIGITS DEPRECIATION}

\section{Total Levelized Power Costs}

Several of the major components of total power costs have been discussed in previous sections. In addition to capital expenses and income taxes are annual operating expenses. These include items such as fuel costs, operation and maintenance expenses, and fixed charges.

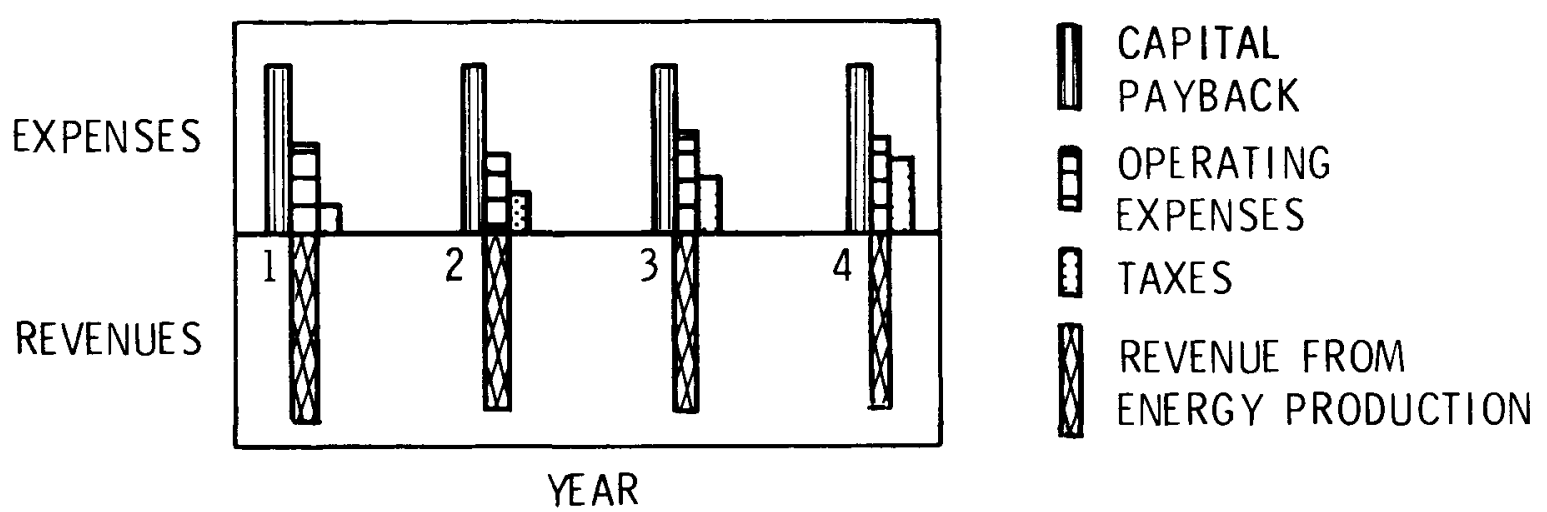


In any year $k$, the expenses may be expressed as:

$$
\begin{aligned}
\text { (expenses) } & =\left(\begin{array}{c}
\text { payment to } \\
\text { principal } \\
\varepsilon \text { interest }
\end{array}\right)+\left(\begin{array}{c}
\text { fixed } \\
\text { charges }
\end{array}\right)+\left(\begin{array}{c}
\text { operation } \\
\text { and } \\
\text { maintenance } \\
\text { costs }
\end{array}\right)+\left(\begin{array}{c}
\text { fuel } \\
\text { cycle } \\
\text { costs }
\end{array}\right)+\text { (income taxes) } \\
\operatorname{Exp}_{k} & =\mathrm{Cap}_{\mathrm{k}}+\mathrm{Fix}_{\mathrm{k}}+\mathrm{OEM}_{\mathrm{k}}+\mathrm{Fuel}_{\mathrm{k}}+\mathrm{Inc}_{\mathrm{k}}
\end{aligned}
$$

where Fuel $_{k}$ represents the fuel expenditure in the year $k$ at the capacity factor of the reactor in that year.

Revenues in each year are determined by a constant, or "levelized," power cost multiplied by the energy produced in that year.

$$
\begin{aligned}
& \left(\begin{array}{c}
\text { revenues in } \\
\text { any year }
\end{array}\right)=\left(\begin{array}{c}
\text { levelized power } \\
\text { cost }
\end{array}\right) \times \quad \text { (energy produced in that year) } \\
& \begin{array}{rllll}
\operatorname{Rev}_{\mathrm{k}} & = & \mathrm{L} & \mathrm{x} & \mathrm{E}_{\mathrm{k}}
\end{array}
\end{aligned}
$$

Each of the revenues and expenses may be present-valued to the year of reactor startup. For instance, the present-worth of Fue $_{k}$ is $\frac{\text { Fuel } l_{k}}{(1+i)^{k}}$.

The levelized power cost, L, will be chosen such that the sum of all the present-valued revenues equals the sum of all the present-valued expenses. This may be expressed as:

$$
\sum_{k=1}^{K} \frac{\operatorname{Rev}_{k}}{(1+i)^{k}}=\sum_{k=1}^{K} \frac{\operatorname{Exp}_{k}}{(1+i)^{k}} \quad \begin{aligned}
& \text { where } K \text { is the lifetime } \\
& \text { of the plant }
\end{aligned}
$$

Using the expressions for $\operatorname{Rev}_{k}$ and $\operatorname{Exp}_{k}$ from above,

$$
L \sum_{k=1}^{K} \frac{E_{k}}{(1+i)^{k}}=\sum_{k=1}^{K} \frac{\mathrm{Cap}_{k}+\mathrm{Fix}_{\mathrm{k}}+0 \mathrm{OqM}_{\mathrm{k}}+\mathrm{Fuel}_{\mathrm{k}}+\mathrm{Inc}_{\mathrm{k}}}{(1+\mathrm{i})^{\mathrm{k}}}
$$


The income tax term, $\mathrm{Inc}_{\mathrm{k}}$, is composed of several components, as previously described:

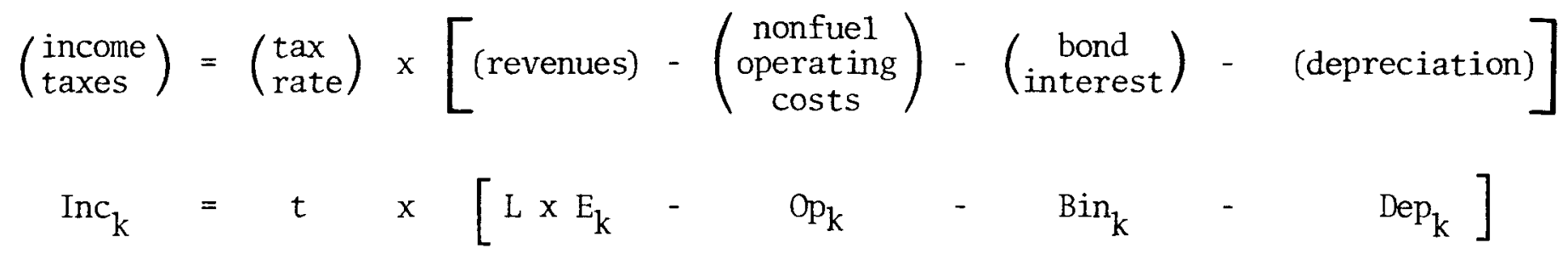
Also,

$$
\begin{aligned}
\left(\begin{array}{c}
\text { nonfuel } \\
\text { operating } \\
\text { costs }
\end{array}\right) & =\left(\begin{array}{c}
\text { fixed } \\
\text { charges }
\end{array}\right)+\left(\begin{array}{c}
\text { operation } \\
\text { and } \\
\text { maintenance } \\
\text { costs }
\end{array}\right) \\
\mathrm{Op}_{\mathrm{k}} & =\mathrm{Fix}_{\mathrm{k}}+\mathrm{OGM}_{\mathrm{k}}
\end{aligned}
$$

And,

$$
\begin{aligned}
(\text { depreciation }) & =\left(\begin{array}{c}
\text { capital } \\
\text { depreciation }
\end{array}\right)+\left(\begin{array}{c}
\text { fuel } \\
\text { depreciation }
\end{array}\right) \\
\operatorname{Dep}_{k} & =\operatorname{CDep}_{k}+\operatorname{FDep}_{k}
\end{aligned}
$$

So the term Inc $_{k}$ can be expressed as:

$$
\operatorname{Inc}_{k}=t x\left(\operatorname{LxE}_{k}-\mathrm{Fix}_{\mathrm{k}}-\mathrm{OGM}_{\mathrm{k}}-\mathrm{Bin}_{\mathrm{k}}-\mathrm{CDep}_{\mathrm{k}}-\mathrm{FDep}_{\mathrm{k}}\right)
$$

This new expression for income taxes may be substituted into Equation 1:

$\mathrm{L} \quad \sum_{\mathrm{k}=1}^{\mathrm{K}} \frac{\mathrm{E}_{\mathrm{k}}}{(1+\mathrm{i})^{\mathrm{k}}}=$
$\quad \sum_{\mathrm{k}=1}^{\mathrm{K}} \frac{\mathrm{Cap}_{\mathrm{k}}+\mathrm{Fix}_{\mathrm{k}}+\mathrm{OGM}_{\mathrm{k}}+\mathrm{Fuel}_{\mathrm{k}}+\mathrm{tx}\left(\mathrm{L} \times \mathrm{E}_{\mathrm{k}}-\mathrm{Fix}_{\mathrm{k}}-\mathrm{OEM}_{\mathrm{k}}-\mathrm{Bin}_{\mathrm{k}}-\mathrm{CDep}_{\mathrm{k}}-\mathrm{FDep}_{\mathrm{k}}\right)}{(1+\mathrm{i})^{\mathrm{K}}}$ 
This equation may now be rearranged and solved for the levelized power cost, L:

$$
\sum_{k=1}^{K} \frac{\mathrm{Cap}_{k}+\mathrm{Fix}_{\mathrm{k}}+\mathrm{OFM}_{\mathrm{k}}+\mathrm{Fuel}_{\mathrm{k}}-\mathrm{tx}\left(\mathrm{Fix}_{\mathrm{k}}+\mathrm{O \& M_{k }}+\mathrm{Bin}_{\mathrm{k}}+\mathrm{CDep}_{\mathrm{k}}+\mathrm{FDep}_{\mathrm{k}}\right)}{(1+\mathrm{i})^{\mathrm{k}}}
$$

$\mathrm{L}=$

$$
\text { (1-t) } \sum_{k=1}^{K} \frac{E_{k}}{(1+i)^{k}}
$$

The equation may be further developed as follows:

$$
\sum_{k=1}^{K} \frac{\mathrm{Cap}_{k}+\mathrm{Fix}_{\mathrm{k}}+\mathrm{OEM}_{\mathrm{k}}+\mathrm{Fuel}_{\mathrm{k}}+\frac{\mathrm{t}}{1-\mathrm{t}}\left(\mathrm{Cap}_{\mathrm{k}}+\mathrm{Fuel}_{\mathrm{k}}-\mathrm{CBin}_{\mathrm{k}}-\mathrm{FBin}_{\mathrm{k}}-\mathrm{CDep}_{\mathrm{k}}-\mathrm{FDep}_{\mathrm{k}}\right)}{(1+\mathrm{i})^{\mathrm{k}}}
$$

$\mathrm{L}=$

$$
\sum_{k=1}^{K} \frac{E_{k}}{(1+i)^{k}}
$$

The terms may then be separated into several major components of levelized total power cost:

Levelized capital expenses (including associated income taxes and fixed charges)

Levelized operation and maintenance expenses

$$
\begin{aligned}
& \int \frac{\sum_{k=1}^{K} \frac{\operatorname{Cap}_{k}+\frac{t}{1-t}\left(\mathrm{Cap}_{k}-\mathrm{CBin}_{k}-\mathrm{CDep}_{k}\right)+\mathrm{Fix}_{k}}{(1+i)^{\mathrm{k}}}}{\sum_{\mathrm{k}=1}^{K} \frac{E_{k}}{(1+i)^{k}}} \\
& \frac{\sum_{k=1}^{K} \frac{O \& M}{(1+i)^{K}}}{\sum_{k=1}^{K} \frac{E_{k}}{(1+i)^{k}}}
\end{aligned}
$$


Levelized fuel cycle expenses (including associated fue 1 cycle taxes)

$$
\left\{\frac{\sum_{k=1}^{K} \frac{\text { Fuel }_{k}+\frac{t}{1-t}\left(\text { Fuel }_{k}-\text { FBin }_{k}-\text { FDep }_{k}\right)}{(1+i)^{k}}}{\sum_{k=1}^{K} \frac{E_{k}}{(1+i)^{k}}}\right.
$$

The computer code, HPC, is based on the preceding definition of levelized power costs. This method of calculating power costs is accurate, but involves extensive computation. An alternative method has been developed which involves far less computation, while producing similar results. This will be discussed in the following section.

Approximate Method for Calculating Levelized Power Costs

The exact expression for levelized power costs was separated into three major power cost components: capital expenses, operation and maintenance expenses, and fuel costs. Each of these components can be handled by the approximate methods developed in this section. There are several advantages in using these approximate techniques. First, power cost estimates may be produced in a timely fashion and without access to a computer. In addition, through the use of these methods, one can quickly identify the major factors contributing to power cost and determine the sensitivity of total power cost to the individual components.

\section{Capital Expenses}

For the purposes of this calculational technique, the capital expenses will include income taxes and fixed charges in addition to the return on and the return of the initial investment. 


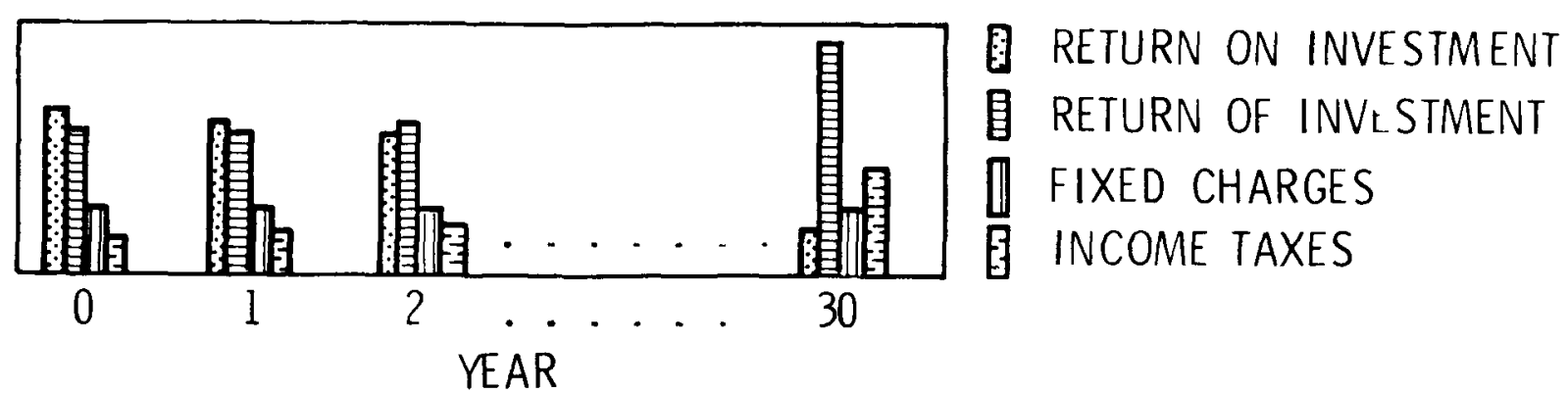

\section{COMPONENTS OF CAPITAL EXPENSES IN THE APPROXIMATE METHOD}

In the exact method of calculating the capital cost component, the charges associated with each year were present-valued to the beginning of the first year and then levelized over the lifetime of the reactor.

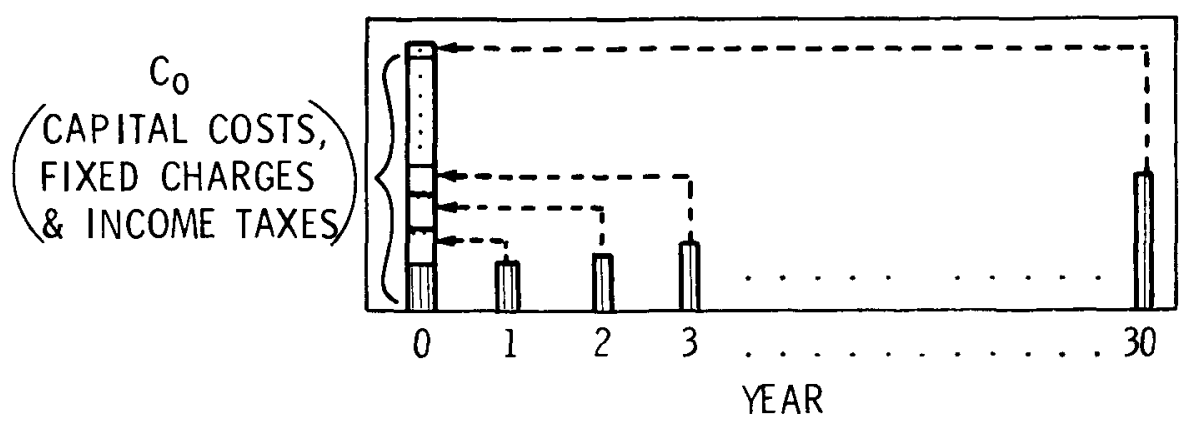

ALL CAPITAL EXPENSES PRESENT-VALUED tO PLANT STARTUP

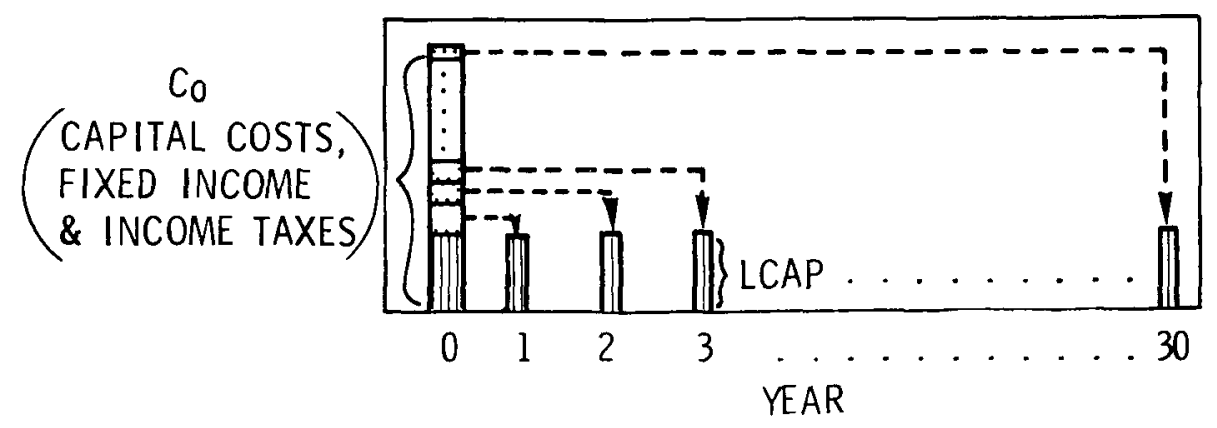

PRESENT-VALUED EXPENSES LEVELIZED OVER PLANT LIFETIME 
An alternative procedure for determining the levelized power cost is the fixed-charge-rate method. The fixed charge rate is defined as the ratio of the annual fixed charges to the original investment. This may be expressed as:

$$
\begin{aligned}
& \text { (fixed charge rate) } \times\left(\begin{array}{c}
\text { initial capital } \\
\text { investment }
\end{array}\right)=\left(\begin{array}{c}
\text { levelized capital } \\
\text { expenses }
\end{array}\right) \\
& \text { FCR } \quad \mathrm{C} \quad \mathrm{C} \quad \text { LCap }
\end{aligned}
$$

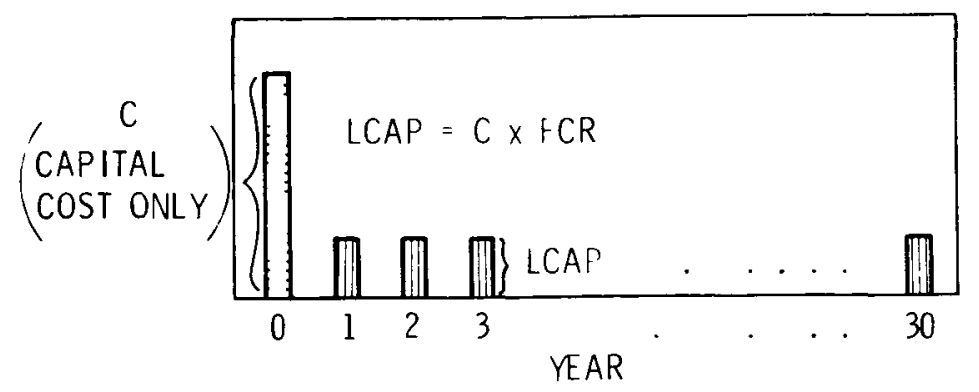

\section{LEVELIZING CAPITAL EXPENSES WITH THE FIXED CHARGE RATE METHOD}

The annual levelized capital costs may be expressed in terms of $\mathrm{mills} / \mathrm{kwh}$ as :

$$
\begin{aligned}
& \left(\begin{array}{c}
\text { annual } \\
\text { evelized } \\
\text { capital } \\
\text { expenses }
\end{array}\right) \quad[\text { mills } / \mathrm{kwh}]=\frac{\left(\begin{array}{c}
\text { initial } \\
\text { capital } \\
\text { investment }
\end{array}\right)[\$] \times\left(\begin{array}{c}
\text { fixed } \\
\text { charge } \\
\text { rate }
\end{array}\right) \times[1000 \mathrm{mills} / \$]}{\left(\begin{array}{c}
\text { total } \\
\text { energy } \\
\text { produced in } \\
\text { one year }
\end{array}\right)[\mathrm{kwe}-\mathrm{yr}] \times[8760 \mathrm{hrs} / \mathrm{yr}]} \\
& \left(\begin{array}{c}
\text { unit capital } \\
\text { cost }
\end{array}\right)[\$ / \text { kwe }] \times\left(\begin{array}{c}
\text { installed } \\
\text { capacity }
\end{array}\right)[\mathrm{kwe}] \times\left(\begin{array}{c}
\text { fixed } \\
\text { charge } \\
\text { rate }
\end{array}\right) \times[1000 \mathrm{mil1s} / \$] \\
& \left.\left(\begin{array}{c}
\text { capacity } \\
\text { factor }
\end{array}\right) \times\left(\begin{array}{c}
\text { installed } \\
\text { capacity }
\end{array}\right) \text { [kwe }\right] \times\left[\begin{array}{ll}
1 & \text { year }] \times[8760 \mathrm{hrs} / \mathrm{yr}]
\end{array}\right.
\end{aligned}
$$




$$
=\frac{\left(\begin{array}{c}
\text { unit capital } \\
\text { cost }
\end{array}\right)[\$ / \text { kwe }] \times\left(\begin{array}{c}
\text { fixed charge } \\
\text { date }
\end{array}\right) \times[1000 \mathrm{mills} / \$]}{\left(\begin{array}{c}
\text { capacity } \\
\text { factor }
\end{array}\right) \times[8760 \mathrm{hrs}]}
$$

or,

$$
\text { LCap }(\mathrm{mi} 11 \mathrm{~s} / \mathrm{kwh})=\frac{\mathrm{UCap}(\$ / \mathrm{kwe}) \times \mathrm{FCR} \times 1000(\mathrm{mills} / \$)}{\mathrm{CF} \times 8760 \mathrm{hrs}}
$$

Operation and maintenance costs

Operation and maintenance expenses are given as constant annual costs. Thus, the only adjustment that must be made is to convert these costs from $\$ /$ kwe-yr to mills $/ \mathrm{kwh}$. The operating costs are divided into fixed and variable components. The plant capacity factor must be used to determine the variable operating costs.

The levelized operation and maintenance costs may be expressed as:

$$
\begin{aligned}
& \left(\begin{array}{c}
\text { levelized } \\
\text { operation and } \\
\text { maintenance } \\
\text { costs }
\end{array}\right) \quad[\text { mills/kwh }] \\
& =\frac{\left(\begin{array}{l}
\text { O\&M expenses } \\
\text { in one year }
\end{array}\right)[\$ / \text { kwe-yr }] \times[1 \text { year }] \times\left(\begin{array}{l}
\text { installed } \\
\text { capacity }
\end{array}\right)[\mathrm{kwe}] \times[1000 \mathrm{mills} / \$]}{\left(\begin{array}{l}
\text { total energy } \\
\text { produced in } \\
\text { one year }
\end{array}\right)[\mathrm{kwe}-\mathrm{yr}] \times[8760 \mathrm{hrs} / \mathrm{yr}]} \\
& =\frac{\text { (O\&M expenses })[\$ / \text { kwe-yr }] \times[1 \text { year }] \times\left(\begin{array}{l}
\text { installed } \\
\text { capacity }
\end{array}\right)[\mathrm{kwe}] \times[1000 \mathrm{mills} / \$]}{\left(\begin{array}{c}
\text { capacity } \\
\text { factor }
\end{array}\right) \times\left(\begin{array}{c}
\text { installed } \\
\text { capacity }
\end{array}\right)[\mathrm{kwe}] \times[1 \text { year }] \times[8760 \mathrm{hrs} / \mathrm{yr}]} \\
& =\quad \text { (OGM expenses) }[\$ / \mathrm{kwe}-\mathrm{yr}] \times[1000 \mathrm{mi11s} / \$] \\
& \left.\begin{array}{c}
\text { capacity } \\
\text { factor }
\end{array}\right) \times \quad[8760 \mathrm{hrs} / \mathrm{yr}]
\end{aligned}
$$




$$
=\frac{\left.\left[\begin{array}{l}
\text { fixed O\&M } \\
\text { expenses }
\end{array}\right)[\$ / \text { kwe-yr }]+\left(\begin{array}{c}
\text { variable } \\
\text { O\&M } \\
\text { expenses }
\end{array}\right)[\$ / \text { kwe-yr }] \times\left(\begin{array}{c}
\text { capacity } \\
\text { factor }
\end{array}\right)\right] \times[1000 \mathrm{mills} / \$]}{\left(\begin{array}{c}
\text { capacity } \\
\text { factor }
\end{array}\right) \times[8760 \mathrm{hrs} / \mathrm{yr}]}
$$

or,

LOEM (mi11s/kwh) $=\frac{\{\text { FO\&M }(\$ / \text { kwe-yr })+[\operatorname{VOEM}(\$ / \mathrm{kwe}-\mathrm{yr}) \times \mathrm{CF}]\} \times 1000(\mathrm{mi} 1 \mathrm{~s} / \$)}{\text { CF } \times 8760(\mathrm{hrs} / \mathrm{yr})}$

Levelized fuel cycle expenses

In the exact expression for the levelized fuel cycle costs, there was a term involving fuel cycle taxes. This term is difficult to handle in a simplified format. Thus, for the purposes of approximating fuel cycle costs, it was assumed that fuel cycle items were expensed. The tax term then drops out and the levelized fuel cycle component is reduced to:

$$
\begin{aligned}
& \text { Levelized fuel } \\
& \text { cycle expenses }
\end{aligned}=\frac{\sum_{k=1}^{K} \frac{\mathrm{Fuel}_{k}}{(1+i)^{k}}}{\sum_{\mathrm{k}=1}^{K} \frac{E_{k}}{(1+i)^{k}}}
$$

Fuel cycle costs will be determined for a single batch of fuel whose costs are representative of the actual levelized costs. The costs associated with this typical or average batch are determined by first calculating the cost of an equilibrium batch of fuel. However, the fuel costs for the first core are much higher than equilibrium costs. The equilibrium costs must therefore be incremented to account for the additional levelized costs associated with the first core. A similar adjustment must also be made to account for excess costs associated with the last core. 
A typical batch may now be represented as:

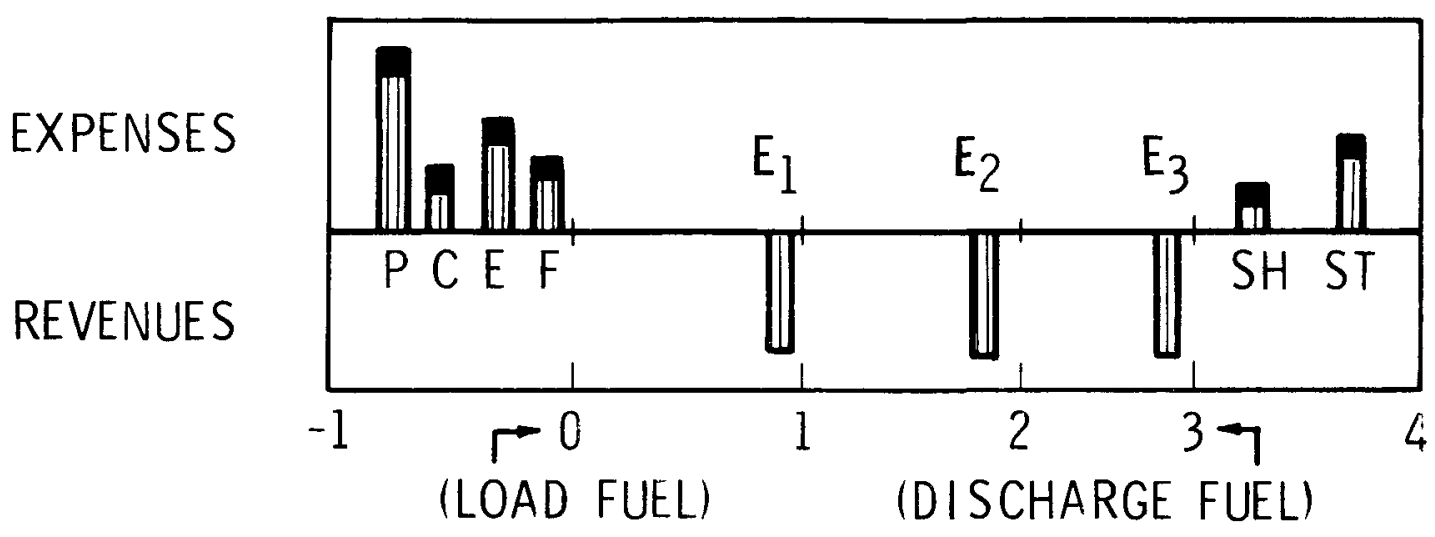

YEAR

P: PURCHASE U $\mathrm{O}_{8}$

C: CONVERSION

E: ENRICHMENT

F: FABRICATION

$\left.\begin{array}{l}E_{1} \\ E_{2} \\ E_{3}\end{array}\right\}$

REVENUES FROM

ENERGY PRODUCTION

\section{COSTS ASSOCIATED WITH A SINGLE BATCH OF FUEL - EQUILIBRIUM COSTS ADJUSTED TO ACCOUNT FOR FIRST AND LAST CORES}

The shaded areas added to each fuel cycle component represent adjustments made for additional costs associated with the first and last batches. These adjustments will be discussed in detail in subsequent sections.

Equilibrium batch - The expenses associated with an equilibrium batch will first be determined. The expression for levelized fuel costs is:

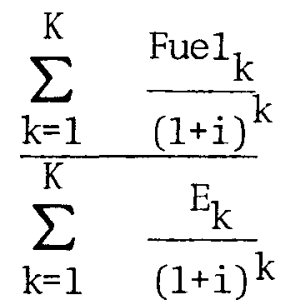


Recall that Fuel $_{k}$ is evaluated at the capacity factor of the reactor in the year $\mathrm{k}$ and that $\mathrm{E}_{\mathrm{k}}$ is the energy production of the reactor in year $\mathrm{k}$. For an equilibrium batch, both $\mathrm{Fuel}_{\mathrm{k}}$ and $\mathrm{E}_{\mathrm{k}}$ are directly proportional to the annual capacity factor. Consequently, the capacity factor may be eliminated from both terms in this expression for an equilibrium batch. The annual fuel expenses may be evaluated using reactor data at $100 \%$ capacity factor if the energy production is also evaluated at a capacity factor of $100 \%$.

The cost associated with each fuel cycle component is determined by the product of the unit cost and the reactor material charge or discharge. For example,

$$
\begin{gathered}
\text { Cost of } \\
\text { fabrication }
\end{gathered}=\frac{\$}{\mathrm{~kg} \text { heavy metal }} \times \frac{\mathrm{kg} \text { heavy metal fabricated }}{\mathrm{kwe} \text { produced-yr }}
$$

The second term represents the kilograms of heavy metal fabricated for one year of power production at a capacity factor of $100 \%$. The expenses associated with an equilibrium batch are all present-valued to the time at which the fuel is loaded into the reactor. If $\mathrm{b}$ represents the number of batches in a reactor, the fuel expenses for a batch may be expressed as:

$\left(\begin{array}{l}\text { present- } \\ \text { valued } \\ \text { fuel costs } \\ \text { for an } \\ \text { equili- } \\ \text { brium } \\ \text { batch }\end{array}\right)(\$ / k w e-y r)=P_{e q}(1+i)+C_{e q}(1+i)+E_{e q}(1+i)+F_{e q}(1+i)+\frac{S_{e q}}{(1+i)^{b+1}}+\frac{S T}{(1+i)^{b+1}}$

The energy production may also be present-valued to the time at which the batch is loaded: 


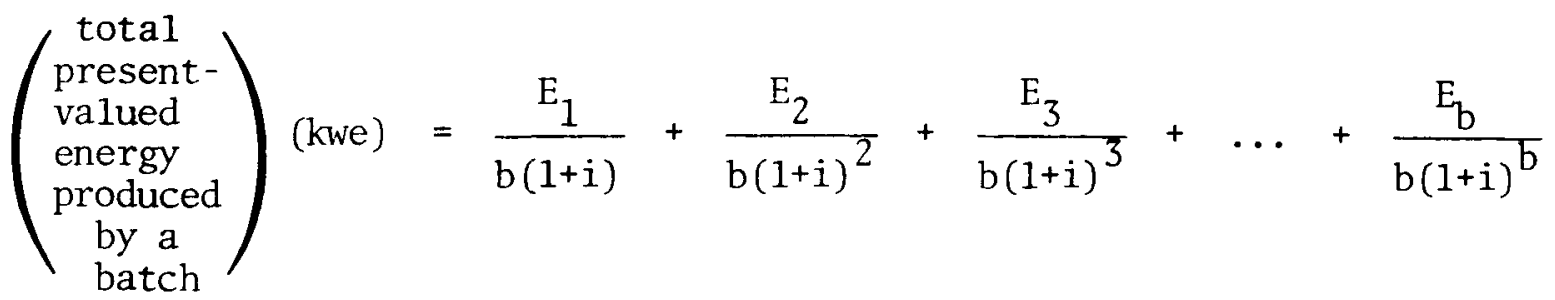

Since the fuel expenditures are evaluated at a capacity factor of $100 \%$, the energy produced is also evaluated at a $100 \%$ capacity factor and $E_{1}=E_{2}=E_{3}=$ $\ldots=E_{b}=E_{100}$.

$$
\left(\begin{array}{c}
\text { total } \\
\text { present- } \\
\text { valued } \\
\text { energy } \\
\text { produced } \\
\text { by a } \\
\text { batch }
\end{array}\right)(k w e)=\frac{E_{100}}{b}\left(\frac{1}{1+i}+\frac{1}{(1+i)^{2}}+\ldots+\frac{1}{(1+i)^{b}}\right)
$$

The levelized fuel expenses for an equilibrium cycle are now the present-valued costs divided by the present-valued revenues:

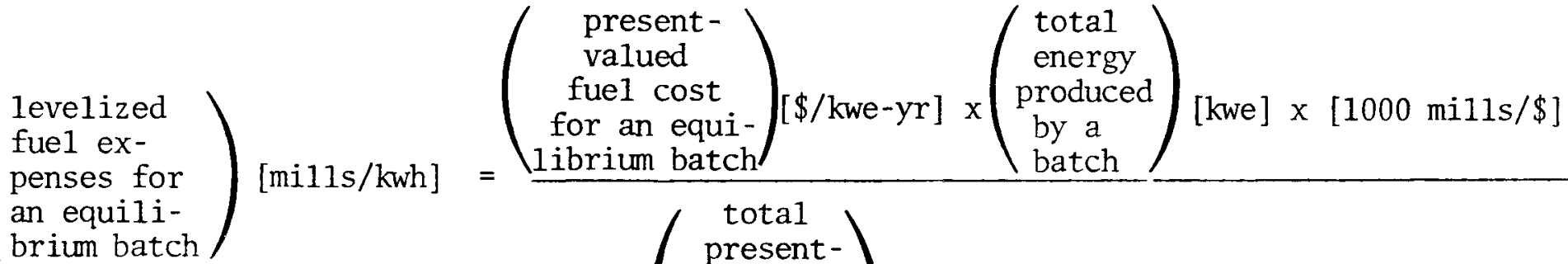

$$
\begin{aligned}
& \left(\begin{array}{c}
\text { total } \\
\text { present- } \\
\text { valued } \\
\text { energy } \\
\text { produced } \\
\text { by a } \\
\text { batch }
\end{array}\right)[\mathrm{kwe}] \quad x \quad[8760 \mathrm{hrs} / \mathrm{yr}]
\end{aligned}
$$

or

$$
\begin{aligned}
& \text { LFue }_{\text {eq }}[\mathrm{mills} / \mathrm{kwh}]= \\
& \frac{\text { Fue1 }_{\mathrm{eq}}[\$ / \mathrm{kwe}-\mathrm{yr}] \times \mathrm{E}_{100}[\mathrm{kwe}] \times[1000 \mathrm{mills} / \$]}{\frac{\mathrm{E}_{100}}{\mathrm{~b}}\left(\frac{1}{(1+\mathrm{i})}+\frac{1}{(1+\mathrm{i})^{2}}+\ldots+\frac{1}{(1+\mathrm{i})^{b}}\right)[\mathrm{kwe}] \times[8760 \mathrm{hrs} / \mathrm{yr}]}
\end{aligned}
$$




$$
=\frac{\text { Fue } 1_{\mathrm{eq}}[\$ / \mathrm{kwe}-\mathrm{yr}] \times[1000 \mathrm{mills} / \$]}{\frac{1}{b}\left(\frac{1}{1+i}+\frac{1}{(1+i)^{2}}+\ldots+\frac{1}{(1+i)^{b}}\right) \times[8760 \mathrm{hrs} / \mathrm{yr}]}
$$

Initial core - The levelized fuel expenses associated with the initial core may also be calculated. The present-valued costs of the first core that are in excess of the present-valued costs of the equilibrium cycle must be determined. For example, the excess cost of purchasing $\mathrm{U}_{3} \mathrm{O}_{8}$ is:

$$
\left\{P_{\text {in }}-\left[P_{\text {eq }} \times\left(\begin{array}{c}
\text { capacity } \\
\text { factor }
\end{array}\right)\right]\right\} \times(1+i)(\$ / \text { kwe })
$$

Note that all these additional costs occur at the beginning of plant operation. The costs may be levelized over the 30 years of plant operation with the amortization formula developed in a previous section:

$$
\left(\begin{array}{c}
\text { annual } \\
\text { additional } \\
\text { cost due to } \\
\text { first core }
\end{array}\right)[\$ / \text { kwe-yr }]=\left(\begin{array}{c}
\text { total excess } \\
\text { costs due to } \\
\text { first core }
\end{array}\right) \times\left[\frac{i x(1+i)^{30}}{(1+i)^{30}-1}\right]
$$

The annual additional expense is then expressed in terms of mills/kwh as:

$\left(\begin{array}{c}\text { levelized } \\ \text { additional } \\ \text { expense due } \\ \text { to first } \\ \text { core }\end{array}\right)$

$$
\text { LFue }_{\text {in }}=\frac{\text { Fue }_{\text {in }}[\$ / \mathrm{kwe}] \times \mathrm{E}_{100}[\mathrm{kwe}] \times[1000 \mathrm{mi11s} / \$]}{\mathrm{CF} \times \frac{E_{100}}{\mathrm{~b}}\left(\frac{1}{1+i}+\frac{1}{(1+\mathrm{i})^{2}}+\ldots+\frac{1}{(1+\mathrm{i})^{\mathrm{b}}}\right)[\mathrm{kwe}] \times[8760 \mathrm{hrs} / \mathrm{yr}]}
$$




$$
=\frac{\text { Fuel }_{\text {in }}[\$ / \text { kwe }-y r] \times[1000 \mathrm{mills} / \$]}{\frac{\mathrm{CF}}{\mathrm{b}} \times\left(\frac{1}{1+i}+\frac{1}{(1+i)^{2}}+\ldots+\frac{1}{(1+i)^{\mathrm{b}}}\right) \times[8760 \mathrm{hrs} / \mathrm{yr}]}
$$

Final core - The excess costs due to the final core discharge are calculated in the same manner as excess costs for the initial core. Since these additional costs occur at the end of the plant lifetime, they must first be present-valued to the year of reactor startup.

$$
\left(\begin{array}{c}
\text { annual } \\
\text { additional } \\
\text { expenses due } \\
\text { to the last } \\
\text { core }
\end{array}\right)[\$ / \text { kwe-yr }]=\left(\begin{array}{c}
\text { total excess } \\
\text { costs due to } \\
\text { last core }
\end{array}\right) \times \frac{1}{(1+i)^{30}} \times\left[\frac{i \times(1+i)^{30}}{(1+i)^{30}-1}\right]
$$

The levelized additional expense due to the last core is now:

$$
\text { LFuel }_{\text {final }}=\frac{\text { Fue }_{\text {final }}[\$ / \text { kwe-yr }] \times[1000 \mathrm{mil1s} / \mathrm{kwh}]}{\frac{\mathrm{CF}}{\mathrm{b}} \times\left(\frac{1}{1+i}+\frac{1}{(1+\mathrm{i})^{2}}+\ldots+\frac{1}{(1+\mathrm{i})^{\mathrm{b}}}\right) \times[8760 \mathrm{hrs} / \mathrm{yr}]}
$$

The total levelized fuel cycle cost may now be obtained by summing the components due to the first, equilibrium, and last cores:

$$
\text { LFuel }_{\text {tot }}=\mathrm{LFuel}_{\text {in }}+\mathrm{LFuel}_{\mathrm{eq}}+\mathrm{LFuel}_{\text {final }}
$$

Now the tota 1 levelized power cost is:

$$
\text { LCap + LOGM + Fuel } 1_{\text {tot }}
$$

Sample Calculation of Total Power Costs of a Standard LWR Using the Approximate Method

As an illustrative example, the steps in calculating the levelized power costs of a standard LWR on the once-through cycle are shown. 
Reactor charge and discharge data (given at $100 \%$ capacity factor for a plant size of $1000 \mathrm{MWe}$ )

\section{$\underline{\text { Item }}$}

$\mathrm{U}_{3} \mathrm{O}_{8}$ charge

Separative work charge

Heavy metal

charge

Heavy metal

discharge

\section{Units}

short tons/GWe-yr

$10^{3} \mathrm{SWU} / \mathrm{GWe}-\mathrm{yr}$

$\mathrm{kg} / \mathrm{GWe}-\mathrm{yr}$

$\mathrm{kg} / \mathrm{Gwe}-\mathrm{yr}$
Initial

Core

376

200

69073

36458

34564

255

153

34564
Final

Batch

255

153

68482

The average annual capacity is $65.9 \%$ and the standard LWR has a three-batch core

Economic data

Discount rate

$4.5 \% / \mathrm{yr}$

Fixed charge rate

$9.8 \% / \mathrm{yr}$

Capital cost (including owner's cost and IDC)

$770 \$ / k w e$

Operation and maintenance costs

Fixed component

$11.2 \$ /$ kwe $-y r$

Variable component

$0.5 \$ /$ kwe-yr

$\mathrm{U}_{3} \mathrm{O}_{8}$ conversion cost

$4 \$ / \mathrm{kg} \mathrm{U}$

Separative work

$100 \$ /$ SWU

Fabrication

$115 \$ / \mathrm{kg} \mathrm{HM}$

Spent fuel shipping

$20 \$ / \mathrm{kg} \mathrm{HM}$

Spent fuel storage

$130 \$ / \mathrm{kg} \mathrm{HM}$

Levelized capita1 expense

$$
\begin{aligned}
\mathrm{LCap}(\mathrm{mills} / \mathrm{kwh}) & =\frac{770(\$ / \mathrm{kwe}) \times 0.098 \times 1000(\mathrm{mills} / \$)}{0.659 \times 8760 \mathrm{hrs}} \\
& =13.07(\mathrm{mills} / \mathrm{kwh})
\end{aligned}
$$


Levelized operation and maintenance expenses

$$
\begin{aligned}
\operatorname{LO\& M}(\mathrm{mills} / \mathrm{kwh}) & =\frac{[11.2(\$ / \mathrm{kwe}-\mathrm{yr})+0.5(\$ / \mathrm{kwe}-\mathrm{yr}) \times 0.659] \times 1000(\mathrm{mills} / \$)}{0.659 \times 8760(\mathrm{hrs} / \mathrm{yr})} \\
& =2.00(\mathrm{mills} / \mathrm{kwh})
\end{aligned}
$$

Levelized fuel cycle expenses (assume that the price of $\mathrm{U}_{3} \mathrm{O}_{8}$ is $40 \$ / 1 b$ for this example)

The levelized fuel cycle expenses associated with an equilibrium batch will first be calculated. This will be followed by expenses associated with the first and last cores. The present-valued costs of the various fuel cycle items are:

$\mathrm{U}_{3} \mathrm{O}_{8}$ purchase:

$$
\begin{aligned}
P_{\text {eq }} \times 1.045 & =[255(\text { tons } / G W e-y r) \times 40(\$ / 1 \mathrm{~b}) \times 2000(1 \mathrm{~b} / \text { ton })] \times 1.045 \\
& =21.32 \times 10^{6}(\$ / G W e-y r)=21.32(\$ / \text { kwe }-y r)
\end{aligned}
$$

$\mathrm{U}_{3} \mathrm{O}_{8}$ conversion to $\mathrm{UF}_{6}$ :

$$
\begin{aligned}
\mathrm{C}_{\mathrm{eq}} \times 1.045 & =\left[255\left(\text { tons } \mathrm{U}_{3} \mathrm{O}_{8} / \mathrm{GWe}-\mathrm{yr}\right) \times 4(\$ / \mathrm{kg} \mathrm{U}) \times 769\left(\mathrm{~kg} \mathrm{U} / \text { tons } \mathrm{U}_{3} \mathrm{O}_{8}\right)\right] \times 1.045 \\
& =0.82 \times 10^{6}(\$ / \text { GWe-yr })=0.82(\$ / \mathrm{kwe}-\mathrm{yr})
\end{aligned}
$$

Enrichment:

$$
\begin{aligned}
E_{e q} \times 1.045 & =[153000(\text { SWU } / \text { GWe-yr }) \times 100(\$ / S W U)] \times 1.045 \\
& =15.99 \times 10^{6}(\$ / \text { GWe-yr })=15.99(\$ / \text { kwe }-y r)
\end{aligned}
$$

Fabrication:

$$
\begin{aligned}
\mathrm{F}_{\mathrm{eq}} \times 1.045 & =[36458(\mathrm{~kg} \mathrm{HM} / \mathrm{GWe}-\mathrm{yr}) \times 115(\$ / \mathrm{kg} \mathrm{HM})] \times 1.045 \\
& =4.38 \times 10^{6}(\$ / \text { GWe-yr })=4.38(\$ / \mathrm{kwe}-\mathrm{yr})
\end{aligned}
$$


Spent fuel shipping:

$$
\begin{aligned}
\mathrm{SH}_{\mathrm{eq}} \times \frac{1}{(1.045)^{4}} & =\left[34564(\mathrm{~kg} \mathrm{HM} / \mathrm{GWe}-\mathrm{yr}) \times 20(\$ / \mathrm{kg} \mathrm{HM}) \times \frac{1}{(1.045)^{4}}\right. \\
& =0.58 \times 10^{6}(\$ / \mathrm{GWe}-\mathrm{yr})=0.58(\$ / \mathrm{kwe}-\mathrm{yr})
\end{aligned}
$$

Spent fuel storage:

$$
\begin{aligned}
\mathrm{ST}_{\text {eq }} \times \frac{1}{(1.045)^{4}} & =[34564(\mathrm{~kg} \mathrm{HM} / \mathrm{GWe}-\mathrm{yr}) \times 130(\$ / \mathrm{kg} \mathrm{HM})] \times \frac{1}{(1.045)^{4}} \\
& =3.77 \times 10^{6}(\$ / \text { GWe-yr })=3.77(\$ / \text { kwe }-\mathrm{yr})
\end{aligned}
$$

Now the sum of the present-valued fuel costs for an equilibrium batch is:

$$
\left.1.045 \times\left(\mathrm{P}_{\text {eq }}+\mathrm{C}_{\text {eq }}+\mathrm{E}_{\mathrm{eq}}+\mathrm{F}_{\mathrm{eq}}\right)+\frac{\left(\mathrm{SH}_{\mathrm{eq}}+\mathrm{ST}_{\mathrm{eq}}\right)}{(1.045)^{4}}\right)=46.86(\$ / \mathrm{kwe}-\mathrm{yr})
$$

The present-valued energy produced by a batch may also be calculated. For a three-batch core, the present-valued energy produced by a single equilibrium batch at $100 \%$ capacity factor is:

$$
\frac{1 \mathrm{GWe}}{3} \times\left(\frac{1}{1.045}+\frac{1}{(1.045)^{2}}+\frac{1}{(1.045)^{3}}\right)=0.92 \mathrm{GWe}
$$

The levelized fuel expenses for an equilibrium batch are now simply the presentvalued expenses divided by the present-valued revenues, or:

$$
\begin{aligned}
\text { LFue1 }_{\mathrm{eq}} & =\frac{46.86(\$ / \mathrm{kwe}-\mathrm{yr}) \times 1(\mathrm{GWe}) \times 1000(\mathrm{mills} / \$)}{0.92(\mathrm{GWe}) \times 8760(\mathrm{hrs} / \mathrm{yr})} \\
& =5.81(\mathrm{mi} 11 \mathrm{~s} / \mathrm{kwh})
\end{aligned}
$$

Now the levelized fuel expenses associated with the initial core will be calculated. Only those present-valued costs associated with the initial core 
that are in excess of the present-valued costs of an equilibrium batch will be considered. Note that the capacity factor of the reactor is $65.9 \%$. Thus, the fuel cycle costs for the equilibrium cycle should be evaluated with reactor data at $65.9 \%$ of full capacity. As before, the present-valued costs of the various fuel cycle items are:

$\mathrm{U}_{3} \mathrm{O}_{8}$ purchase:

$$
\begin{aligned}
P_{\text {in }} \times 1.045 & =\{[376-(255 \times 0.659)] \times 40 \times 2000\} \times 1.045 \\
& =17.39(\$ / \text { kwe })
\end{aligned}
$$

$\mathrm{U}_{3} \mathrm{O}_{8}$ conversion to $\mathrm{UF}_{6}$ :

$$
\begin{aligned}
C_{\text {in }} \times 1.045 & =\{[376-(255 \times 0.659)] \times 4 \times 769\} \times 1.045 \\
& =0.67(\$ / \text { kwe })
\end{aligned}
$$

Separative work:

$$
\begin{aligned}
E_{\text {in }} \times 1.045 & =\{[200,000-(153,000 \times 0.659)] \times 100\} \times 1.045 \\
& =10.36(\$ / \text { kwe })
\end{aligned}
$$

Fabrication:

$$
\begin{aligned}
F_{\text {in }} \times 1.045 & =\{[69073-(36458 \times 0.659)] \times 115\} \times 1.045 \\
& =5.41(\$ / \mathrm{kwe})
\end{aligned}
$$

The sum of the excess fuel cycle costs due to the initial core is:

$$
1.045 \times\left(P_{\text {in }}+C_{\text {in }}+E_{\text {in }}+F_{\text {in }}\right)=33.83(\$ / k w e)
$$


Amortize the excess costs over the 30 years of plant operation:

$$
\begin{aligned}
\left(\begin{array}{l}
\text { annual } \\
\text { additional } \\
\text { cost due to } \\
\text { first core }
\end{array}\right) & =33.83 \times\left[\frac{0.045 \times(1.045)^{30}}{(1.045)^{30}-1}\right] \\
& =2.08(\$ / \text { kwe-yr })
\end{aligned}
$$

The annual expense due to the first core may now be expressed in terms of mil1s/kwh:

$$
\begin{aligned}
\text { LFue1 }_{\text {in }} & =\frac{2.08(\$ / \mathrm{kwe}-\mathrm{yr}) \times 1(\mathrm{GWe}) \times 1000(\mathrm{mil1s} / \$)}{0.659 \times 0.92(\mathrm{GWe}) \times 8760(\mathrm{hrs} / \mathrm{yr})} \\
& =0.39(\mathrm{mills} / \mathrm{kwh})
\end{aligned}
$$

In a similar fashion, the levelized fuel expenses associated with the final core discharge may be determined. The present-valued costs associated with the final core discharge that are in excess of the present-valued costs of an equilibrium batch are:

Spent fuel shipping:

$$
\begin{aligned}
\mathrm{SH}_{\text {final }} \times \frac{1}{(1.045)^{4}} & =\{[68482-(34564 \times 0.659)] \times 20\} \times \frac{1}{(1.045)^{4}} \\
& =0.77(\$ / \mathrm{kwe})
\end{aligned}
$$

Spent fuel storage:

$$
\begin{aligned}
\mathrm{ST}_{\text {fina } 1} \times \frac{1}{(1.045)^{4}} & =\{[68482-(34564 \times 0.659)] \times 130\} \times \frac{1}{(1.045)^{4}} \\
& =4.98(\$ / \text { kwe })
\end{aligned}
$$


The sum of the excess fuel cycle costs due to the final core discharge is:

$$
\frac{1}{(1.045)^{4}} \times\left(\mathrm{SH}_{\text {final }}+\mathrm{ST}_{\text {final }}\right)=5.75(\$ / \mathrm{kwe})
$$

These additional costs occur at the end of the plant lifetime. They must first be present-valued to the beginning of plant operation and then amortized over the 30 years of plant operation:

$$
\begin{aligned}
\left(\begin{array}{c}
\text { annual } \\
\text { additiona1 } \\
\text { cost due to } \\
\text { last core } \\
\text { discharge }
\end{array}\right) & =5.75 \times \frac{1}{(1.045)^{30}} \times\left[\frac{0.045 \times(1.045)^{30}}{(1.045)^{30}-1}\right] \\
& =0.09(\$ / \text { kwe-yr })
\end{aligned}
$$

The annual expense due to the last core discharge is now:

$$
\begin{aligned}
\text { LFuel }_{\text {final }} & =\frac{0.09(\$ / \mathrm{kwe}-\mathrm{yr}) \times 1(\mathrm{GWe}) \times 1000(\mathrm{mi} 11 \mathrm{~s} / \$)}{0.659 \times 0.92(\mathrm{GWe}) \times 8760(\mathrm{hrs} / \mathrm{yr})} \\
& =0.02(\mathrm{mi1} 1 \mathrm{~s} / \mathrm{kwe})
\end{aligned}
$$

The annual costs due to the first and last cores may now be added to the equilibrium fuel costs to obtain the total levelized fuel cycle expenses:

$$
\text { LFue }_{\text {in }}+\text { LFuel }_{\text {eq }}+\text { LFuel }_{\text {final }}=6.22(\mathrm{mills} / \mathrm{kwh})
$$

The total power cost for the LWR may be obtained by summing capital expenses, operation and maintenance expenses, and fuel cycle costs:

$$
\text { LCap }+ \text { LO\&M }+ \text { LFue1 }=21.29(\mathrm{mills} / \mathrm{kwh})
$$


Sample Calculation of Tota1 Power Costs of an FBR Using the Approximate Method

Reactor charge and discharge data (given at $100 \%$ capacity factor

for a plant size of $1000 \mathrm{MWe}$ )

\begin{tabular}{|c|c|c|c|c|c|}
\hline Item & Zone & $\begin{array}{l}\text { Number of } \\
\text { Batches }\end{array}$ & $\begin{array}{l}\text { Initial } \\
\text { Core }\end{array}$ & $\begin{array}{c}\text { Equilibrium } \\
\text { Batch }\end{array}$ & $\begin{array}{l}\text { Final } \\
\text { Batch }\end{array}$ \\
\hline \multirow{3}{*}{$\begin{array}{l}\text { Heavy metal } \\
\text { charge } \\
(\mathrm{kg} / \mathrm{GWe}-\mathrm{yr})\end{array}$} & Core & 3 & 30392 & 17845 & 17845 \\
\hline & $\begin{array}{l}\text { Axia1 } \\
\text { blanket }\end{array}$ & 3 & 15357 & 9017 & 9017 \\
\hline & $\begin{array}{l}\text { Radial } \\
\text { blanket }\end{array}$ & 6 & 27648 & 6525 & 6525 \\
\hline \multirow{3}{*}{$\begin{array}{l}\text { Heavy metal } \\
\text { discharge } \\
(\mathrm{kg} / \mathrm{GWe}-\mathrm{yr})\end{array}$} & Core & & 17560 & 17560 & 30392 \\
\hline & $\begin{array}{l}\text { Axial } \\
\text { blanket }\end{array}$ & & 8871 & 8871 & 15357 \\
\hline & $\begin{array}{l}\text { Radial } \\
\text { blanket }\end{array}$ & & 6387 & 6387 & 276 \\
\hline
\end{tabular}

The average annual capacity factor is $65.9 \%$
$\underline{\text { Economic data }}$
Discount rate
$4.5 \% / \mathrm{yr}$
Fixed charge rate
$9.8 \% / \mathrm{yr}$
Capital cost (including owner's cost and IDC) at 1.5 times
that of the LWR
$1155 \$ /$ kwe
Operation and maintenance costs
Fixed component
$11.7 \$ /$ kwe-yr
Variable component
$0.9 \$ /$ kwe-yr
Fabrication
Core
$1750 \$ / \mathrm{kg} \mathrm{HM}$
Axial blanket
$35 \$ / \mathrm{kg} \mathrm{HM}$ 
Radial blanket

Total back-end fuel cycle cost

(a11 zones)
$250 \$ / \mathrm{kg} \mathrm{HN}$

$570 \$ / \mathrm{kg} \mathrm{HN}$

\section{Levelized capital expense}

$$
\begin{aligned}
\operatorname{LCap}(\mathrm{mil1s} / \mathrm{kwh}) & =\frac{1155(\$ / \mathrm{kwe}) \times 0.098 \times(1000 \mathrm{mi} 11 \mathrm{~s} / \$)}{0.659 \times 8760 \mathrm{hrs}} \\
& =19.61(\mathrm{mi11s} / \mathrm{kwh})
\end{aligned}
$$

Levelized operation and maintenance expenses

$$
\begin{aligned}
\operatorname{LOGM}(\mathrm{mills} / \mathrm{kwh}) & =\frac{[11.7(\$ / \mathrm{kwe}-\mathrm{yr})+0.9(\$ / \mathrm{kwe}-\mathrm{yr}) \times 0.659] \times 1000(\mathrm{mi} 11 \mathrm{~s} / \$)}{0.659 \times 8760(\mathrm{hrs} / \mathrm{yr})} \\
& =2.13(\mathrm{mills} / \mathrm{kwh})
\end{aligned}
$$

Levelized fuel cycle expenses

The levelized fuel cycle expenses associated with an equilibrium batch will be calculated. The present-valued costs of each fuel cycle item are:

Fabrication:

$$
\begin{aligned}
F_{\text {eq }} \times 1.045 & =[17845(\mathrm{~kg} \mathrm{HM} / \mathrm{GWe}-\mathrm{yr}) \times 1750(\$ / \mathrm{kg} \mathrm{HM})] \times 1.045 & \text { (core) } \\
& +[9017(\mathrm{~kg} \mathrm{HM} / \mathrm{GWe}-\mathrm{yr}) \times 35(\$ / \mathrm{kg} \mathrm{HM})] \times 1.045 & \begin{array}{c}
\text { (axial } \\
\text { blanket) }
\end{array} \\
& +[6525(\mathrm{~kg} \mathrm{HM} / \mathrm{GWe}-\mathrm{yr}) \times 250(\$ / \mathrm{kg} \mathrm{HM})] \times 1.045 & \begin{array}{c}
\text { (radial } \\
\text { blanket) }
\end{array} \\
& =34.67 \times 10^{6}(\$ / \mathrm{GWe}-\mathrm{yr})=34.67(\$ / \mathrm{kwe}-\mathrm{yr}) &
\end{aligned}
$$

Total back-end costs for core and axial blanket:

$B_{e q}(\operatorname{core}+A B) \times \frac{1}{(1.045)^{4}}=[17560(\mathrm{~kg} \mathrm{HM} / \mathrm{GWe}-\mathrm{yr}) \times 570(\$ / \mathrm{kg} \mathrm{HM})] \times \frac{1}{(1.045)^{4}}($ core $)$ 
$+[8871(\mathrm{~kg} \mathrm{HM} / \mathrm{GWe}-\mathrm{yr}) \times 570(\$ / \mathrm{kg} \mathrm{HM})] \times \frac{1}{(1.045)^{4}}$ (axianket)

$=12.63 \times 10^{6}(\$ /$ GWe $-y r)=12.63(\$ /$ kwe - yr $)$

Total back-end costs for the radial blanket:

$$
\begin{aligned}
B_{e q}(\mathrm{RB}) \times \frac{1}{(1.045)^{7}} & =[6387(\mathrm{~kg} \mathrm{HM} / \mathrm{GWe}-\mathrm{yr}) \times 570(\$ / \mathrm{kg} \mathrm{HM})] \times \frac{1}{(1.045)^{7}} \\
& =2.68 \times 10^{6}(\$ / \mathrm{GWe}-\mathrm{yr})=2.68(\$ / \mathrm{kwe}-\mathrm{yr})
\end{aligned}
$$

Now the sum of the present-valued fuel costs for an equilibrium batch is:

$$
\left(F_{\text {eq }} \times 1.045\right)+\left(B_{\text {eq }}(\text { core }+A B) \times \frac{1}{(1.045)^{4}}\right)+\left(B_{\text {eq }}(R B) \times \frac{1}{(1.045)^{7}}\right)=49.98(\$ / \text { kwe }-y r)
$$

The present-valued energy produced by a batch at $100 \%$ capacity factor is:

$$
\frac{1 \text { GWe }}{3} \times\left(\frac{1}{1.045}+\frac{1}{(1.045)^{2}}+\frac{1}{(1.045)^{3}}\right)=0.92 \text { GWe }
$$

The levelized fuel expenses for an equilibrium batch are now:

$$
\begin{aligned}
\text { LFue1 }_{\mathrm{eq}} & =\frac{49.98(\$ / \mathrm{kwe}-\mathrm{yr}) \times 1(\mathrm{GWe}) \times 1000(\mathrm{mi} 1 \mathrm{~s} / \$)}{0.92(\mathrm{GWe}) \times 8760(\mathrm{hrs} / \mathrm{yr})} \\
& =6.20(\mathrm{mi1} 1 \mathrm{~s} / \mathrm{kwh})
\end{aligned}
$$

The levelized fuel expenses associated with the initial core will now be determined. The present-valued costs of the initial core that are in excess of the present-valued costs of an equilibrium batch are:

Fabrication:

$$
\begin{aligned}
F_{\text {in }} \times 1.045 & =\{[30392-(17845 \times 0.659)] \times 1750\} \times 1.045 & \text { (core) } \\
& +\{[15357-(9017 \times 0.659)] \times 35\} \times 1.045 & \begin{array}{l}
\text { (axial } \\
\text { blanket) }
\end{array}
\end{aligned}
$$




$$
\begin{aligned}
& +\{[27648-(6525 \times 0.659)] \times 250\} \times 1.045 \quad \begin{array}{c}
\text { (radial } \\
\text { blanket })
\end{array} \\
& =40.52(\$ / \mathrm{kwe})
\end{aligned}
$$

The excess costs may be amortized over the 30 years of plant operation:

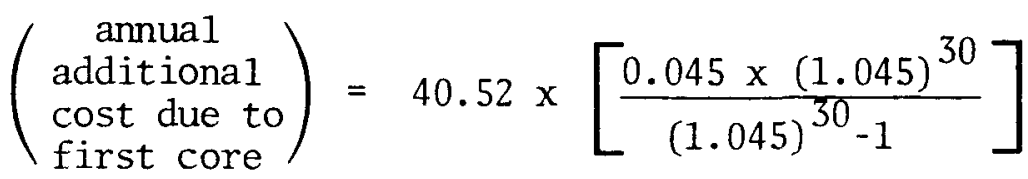

$$
\begin{aligned}
& =2.49(\$ / \text { kwe-yr })
\end{aligned}
$$

The annual expense due to the first core is now:

$$
\begin{aligned}
\text { LFue1 }_{\text {in }} & =\frac{2.49(\$ / \mathrm{kwe}-\mathrm{yr}) \times 1(\mathrm{GWe}) \times 1000(\mathrm{mills} / \$)}{0.659 \times 0.92(\mathrm{GWe}) \times 8760(\mathrm{hrs} / \mathrm{yr})} \\
& =0.47(\mathrm{mil1s} / \mathrm{kwh})
\end{aligned}
$$

Finally, the levelized fuel expenses associated with the final core discharge may be calculated. The present-valued costs of the final core that are in excess of the present-valued costs of an equilibrium batch are:

Total back-end costs for the core and axial blanket:

$$
\begin{aligned}
B_{\text {final }}(\text { core }+A B) \times \frac{1}{(1.045)^{4}} & =\{[30392-(17560 \times 0.659)] \times 570\} \times \frac{1}{(1.045)^{4}} \text { (core) } \\
& +\{[15357-(8871 \times 0.659)] \times 570\} \times \frac{1}{(1.045)^{4}} \begin{array}{l}
\text { (axial } \\
\text { blanket })
\end{array} \\
& =13.65(\$ / \mathrm{kwe})
\end{aligned}
$$

Total back-end costs for the radial blanket:

$$
\begin{aligned}
B_{\text {final }}(\mathrm{RB}) \times \frac{1}{(1.045)^{7}} & =\{[27648-(6387 \times 0.659)] \times 570\} \times \frac{1}{(1.045)^{7}} \\
& =9.82(\$ / \mathrm{kwe})
\end{aligned}
$$


The sum of the excess fuel cycle costs due to the final core discharge is $23.36(\$ / k w e)$.

These costs are first present-valued to the plant startup and then amortized over the 30 years of plant operation:

$$
\begin{aligned}
\left(\begin{array}{c}
\text { annual } \\
\text { additiona1 } \\
\text { cost due to } \\
\text { final core } \\
\text { discharge }
\end{array}\right) & =23.36 \times \frac{1}{(1.045)^{30}} \times\left[\frac{0.045 \times(1.045)^{30}}{(1.045)^{30}-1}\right] \\
& =0.38(\$ / \text { kwe-yr })
\end{aligned}
$$

The annual levelized expense due to the last core discharge is now:

$$
\begin{aligned}
\text { LFuel }_{\text {final }} & =\frac{0.38(\$ / \mathrm{kwe}-\mathrm{yr}) \times 1(\mathrm{GWe}) \times 1000(\mathrm{mills} / \$)}{0.659 \times 0.92(\mathrm{GWe}) \times 8760(\mathrm{hrs} / \mathrm{yr})} \\
& =0.07(\mathrm{mill} / \mathrm{s} / \mathrm{kwh})
\end{aligned}
$$

The total levelized fuel cycle expenses are:

$$
\mathrm{LFue}_{\text {in }}+\mathrm{LFue}_{\text {eq }}+\mathrm{LFue}_{\text {final }}=6.74(\mathrm{mi11 \textrm {s }} / \mathrm{kwh})
$$

The total power cost for the FBR at a capital cost of 1.5 times that of the LWR is:

$$
\text { LCap }+ \text { LO\&M }+ \text { LFue1 }=28.48(\mathrm{mi} 11 \mathrm{~s} / \mathrm{kwh})
$$

